\title{
WHAT ARE WE DOING FOR THE CRIMINAL?
}

Any one entering one of our criminal courts of inferior jurisdiction early in the morning will at once be impressed by the long line of prisoners in the pen awaiting a hearing. $\mathrm{He}$ will see young men and old men, well-dressed women of the street and unkempt old hags. $\mathrm{He}$ will find boys, accused of breaking the city ordinance against bicycle racing on the streets, shoulder to shoulder with hopeless "drunks" and "disorderlies" or with men charged with such serious crimes as may cause them to be held for the Grand Jury. Some few in that long line seem impressed and frightened by their surroundings; the majority look on listlessly and indifferently.

The wheels of Justice now begin to move; one by one the prisoners are called to the bar. I take a couple of typical cases from actual observation.

It is M. A.'s turn. She is a well-dressed, well-rouged woman of unmistakable antecedents. Some professional bondsman has bailed her out overnight; so she has not missed her toilet artifices. The detective who made the arrest testifies against her. She indignantly denies his charge and in a loud voice asserts the purity of her womanhood, which her face belies. Everybody in the "temple of justice" laughs. It is a very sorry spectacle to see the officers of the law laugh at a woman (even though a guilty one) defending her womanhood (even though basely dishonored).

And after all is said, Justice from her throne declares, "Thou art guilty, and a fine of five dollars is imposed upon thee. Go and sin no more!" The fine is paid, Justice is satisfied, ruat coelum! My lady departs with a snicker on her lips which speaks volumes as to the effect of the sentence just imposed.

The next prisoner called is a poor, old wreck of a woman; there is death in her face, but also the resolve to die hard. A rag of a veil over her gray, unkempt hair tells of past coquetries. Poor wretch! she got tired waiting for her 
turn so she had squatted on the floor of the pen. The old sinner, charged with intoxication, bases her defence on the ground that the accusing officer is "a liar." She is discharged with a reprimand.

I have described this nauseating picture for the purpose of showing the absurdity and inefficacy of our penal provisions even in their simplest forms.

Those two women (they are not figments of the imagination) represented the beginning and the end of a career of public unrighteousness which the social state is bound to and does endeavor to prevent. The question is, "How does it seek to prevent it?" In this illustrative case it sought to prevent it by imposing a fine of five dollars, which the guilty woman will provide for by raising the price of her sin on her next expedition. Has the state helped her thereby? Has it protected its good members from her contamination by such means? And, above all, has it done its best to prevent that woman from repeating her crime?

This does not involve the question of police laxity or of collusion; it is a far deeper and more difficult problem, for it goes to the inherent weakness and inefficacy of the penalty provided for the offence.

The evil of such a system is due to our adherence to what can only be called a legal anachronism in our day, the principle that "the punishment should fit the crime" and that the object of a penal provision is retribution for the offence. Starting upon this assumption civilized nations have contended with barbarous ones in inventing penalties of the most refined and atrocious cruelty and in devising methods by which death itself should be as lingeringly painful as possible. Burning, hanging, impaling, sawing asunder, flaying or burying alive, boiling, blowing from the mouth of a cannon,- - these are some of the methods which the law, which can do no wrong, has sanctioned and by which it hoped to repress evil-doing and mete out justice.

But an assumption which legalizes such results is revolting to enlightened mankind. Not only in our day, but centuries ago, long before the modern movement for penal reform began, great men spoke the true word regarding this question. Plato, Seneca and Aristotle declared the reforma- 
tion of the criminal to be one of the main objects of penal justice, and St. Augustine bade us look upon crime as a moral malady which it is our duty to cure.

The verdict of all thoughtful men is well-nigh unanimous to-day that it is the remedy, and' not the pimishment, that should fit the crime, or, more correctly, that should fit the criminal. Many of us may repudiate the teachings of Continental criminologists, but who, after thought and observation, will deny that criminals, "if not so by heredity . . . are largely made so by environment; that they are either physical degenerates or brutalized by vice; that they have lost the power of distinguishing rìght from wrong and commonly lack will-power and so are incapable of changing their habits without external influence?" (Charles Dudley Warner before the National Prison Congress, at Indianapolis, 1898 .)

It has always been my contention that the first duty of the state is to protect its good members; if I now plead for a juster treatment of evil-doers, I do not do so at the cost of inconsistency, for, as Professor Collin has ably put it, "the transformation of the criminal into a serviceable member of society is the only effective protection of society against him."

The classic system of criminal law has never had such an aim in view, and our present penal system, in so far as it follows classic precedents, is bad and necessarily barren of good results.

- According to the official statistics of New York State for I899, of 3,428 persons convicted in the courts of the state 899 had been convicted at least once before. Fully 40 per cent of all offenders in ten countries publishing official reports are old offenders who have been previously imprisoned. Mr. Tallack, of the London Howard Association, has computed that 98 per cent of all convictions in England and Wales are for sentences for less than one year, while in New York 70 per cent of all felon prisoners were, when convicted, under thirty years of age.

This short summary is a terrible indictment against the present system of penal justice.

If 40 per cent of our prisoners are recidivists, then our 
penal system is to a great extent useless as a preventive and deterrent to a repetition of evil deeds. And no wonder, for if 98 per cent of convictions are for terms of less than one year, what good can come of such confinement except on the theory that imprisonment will work a miraculous, sudden conversion! But those figures tell us something more; they tell us that 70 per cent of all felon prisoners were under thirty years of age when convicted; in other words, these felons were young men, young enough to be responsive to proper stimuli; men who, under proper treatment, might still be brought back to righteousness and health.

And herein lies the viciousness of our system, in that it overlooks the fact that crime, like disease, needs individual treatment; that to send some criminals to jail for a week, or a month, or a year, as our laws provide, is about as useful as it would be to send a hopeless consumptive to the mountains for a fortnight.

If modern penologic study has proved anything it is this : that some criminals are chronic and incorrigible offenders even though they are guilty of nothing worse than vagrancy or professional pauperism; that, on the other hand, there are men who are sufficiently punished and helped to reform their lives by the mere fact of being brought into court; to sentence these men to prison, as we have been doing, is to convert an otherwise good citizen into an enemy of social order. As Dr. Wines ably sums up this question, "Too much use is made of the prison. Multitudes of convicts are in confinement, whose release would work no possible harm to society and who deteriorate in prisons. They have not been wrongfully convicted, but they are needlessly held There are others who, having been convicted, would have been more likely to amend their ways if never incarcerated." (F. H. Wines' "Punishment and Reformation").

To this we might add the testimony of one who is most competent to speak on the subject, Mr. Charlton T. Lewis, President of the Prison Association of New York. "With all the solemnity and emphasis of which I am capable," he says, "I utter the profound conviction, after twenty years of con- 
stant study of our prison population, that more than ninetenths of them ought never to have been confined."

The most hopeful sign of popular discontent against classic penal provisions is the introduction in many of our states of the "Indețerminate Sentence" and the "Suspension of Judgment," The fight for their introduction into our criminal codes has been a hard one, and, even where successful, it has been but partially so. No state recognizes an absolutely indeterminate or indefinite sentence; the so-called "indeterminate sentence" wherever in force is applicable only to certain criminals and to certain classes of crimes, and it is indeterminate only as regards the reduction of the maximum penalty imposed, which is fixed by the court. It can be less than the term fixed, but it cannot be more.

It is clear, however, that if a sentence is to be in any way reformatory it must take into account the character of the criminal rather than that of the crime, and that it is impossible to state beforehand how long it will take to effect a satisfactory reformation. Taking a case from the field of medicine, no work on therapeutics can fix $a$ priori the dose and the length of time required for a given drug to produce certain effects. Not even the family physician, in full knowledge of the constitution and idiosyncrasies of his patient, can tell beforehand how long it will take for such a drug and such a treatment to work a cure. It is only by actual experiment and experience, by an increase or diminution of the dose, or by varying the treatment to meet varying symptoms and by careful observation and use of those remedies to which his patient most readily responds, that a cure can be effected. If the physical man needs such treatment, how much more is a similar course necessary in the case of the psycho-physical and moral malady?

In conclusion let me say that the majority of us have failed to give sufficient attention and thought to the problem of the treatment of the criminal. We have been brought up in the old-fashioned belief that, since the criminal is a danger to society, the best thing to do with him is to put him in a good strong cage where he may improve or deteriorate, we care not which. We have been blind to the fact that such a plan is exactly the same in effect as "if one should 
cage a man-eating tiger for a month or a year, and then turn him loose."

There can be no safety in such a system; the only sure way is to endeavor to change the enemy of society into its friend. To this end the law should provide means for holding the law-breakers until they become law-abiders. This can only be done by the introduction of the absolutely indeterminate sentence and by changing the basic principle of our penal codes from that of retribution to that of reformation. And if reformation is in some cases impossible, let society have the right to the perpetual restraint of its implacable and incorrigible enemies.

This is no new plea; it has been discussed and debated and defended by many able students of crime and sociology since the genial writings of Beccaria and the practical reforms of Howard first attracted the attention of mankind to the problem of the criminal.

Nor is this a sentimental plea, for the awakening of a pathetic and piteous interest towards evil-doers. Criminal life, no matter what the cause, is alway repulsive, and no amount of imagination or pity can cover its disgusting aspect. A little sympathy, a little fellow-feeling for the fallen and the criminal will certainly be helpful, just as it is helpful to those who suffer from other ills. But what is needed most is the enactment of laws more in consonance with penologic, sociologic and scientific teachings; laws that will make possible a more correct and just diagnosis of a criminal act and render a judicial sentence not a mere guess at what will be sufficient retributive punishment for an evil act, but a prognosis thereof and the application of a remedial agency.

There will be cases where no cure is possible; but the majority of cases, as is shown by the reformatories of New York and Massachusetts, will respond to such a scientific treatment.

Let us hope that the day is near when the volume of our laws, which bears the title "Crimes and Their Punishments," will be replaced by a treatise on "The Therapeutics of Crime."

Prison Association of Nero York.

Gino C. Speranza. 